\title{
Corporate capitalism, the end of a doctrine - Abstractionism or creative destruction?
}

\begin{abstract}
Capitalism as a system began after departing from feudal structures after the middle of the 16th century. It has now passed through three phases: commercial capitalism; industrial capitalism; and corporate or transnational capitalism. The process of worker alienation began in the phase of industrialisation and has led to complete commodification and to the abstraction of human beings, not only from others but also from self. On the capital side, a certain degree of alienation is also taking place in terms of its roles and way of use. This is leading to the opening up of new forms of ethical and moral norms, as well as a setting of new values, made manifest through various forms of reform of social systems. It is possible to observe work as an engine of productive relations, not only in terms of productivity but also in terms of its ethical and moral principles. Current events point to the problem of finding a permanent solution in the form of a new ethical doctrine which has for its goal a review of the objective scope and historical restrictions of capitalist methods of production.
\end{abstract}

Keywords: capitalism, commodification, crisis, alienation, abstractionism, stock market, the market

Commodification to abstractionism - along the development path of capitalism: introductory remarks

In its essence, capitalism leads to a concentration of capital, employment and power. At one and the same time, capitalism emphasises the power of competition and of monopoly. The result of these assumptions has been the creation of large corporations that have gravitated toward vertical and horizontal forms of integration in terms of controlling the market and competitors, and also in shaping consumer tastes. However, the inconsistency of micro- and macro-economic systems, when the planning system is at stake, has dictated the appearance of global crises in the $30 \mathrm{~s}, 70 \mathrm{~s}, 80 \mathrm{~s}$ and even today.

Looking at the evolutionary development of capitalism, we can see that its introductory phase was merchant capitalism, which lasted until the early eighteenth century. For young nation states, it was convenient to provide monopolistic protection for trading companies. 
Due to the development of industry and the invention of the steam engine, the previous phase of capitalism was replaced by industrial capitalism. Via a phase based on competition:

When one company is growing in relation to the industry, such a company reaches a certain level where further expansion within the industry reduces the efficiency of operations. Then it is necessary to exit from that industry and classify production by branch and geography. ${ }^{1}$

This clearly indicates that the fundamental economic entities within developed capitalism are large corporations with a multinational prefix and a conglomerate style of activity. At first glance, the role of the state is not dominant but, in any case, this role is defined as a strategic and partner-based one for large corporations. With its instruments, a state may accelerate technological progress, shape the workforce through the education system, invest in infrastructure and the environment and take risks in this regard, subsidise unprofitable industries and so on. ${ }^{2}$ Here, we recognise that phase of development which economists call state-monopoly capitalism.

However, this rapid development of capitalism with state support opened the way for the internationalisation of the economy. This has necessitated the need for planning on an international basis, surpassing the borders of nation states. The solution has been found in multinational and transnational companies that cross state borders, so hence one can speak of transnational capitalism.

With the growth of large corporations have come major changes in the labour force, too. The design of corporate organisation is complex, containing a large number of employees, a conglomerate structure, a wholesale market and more than one owner of capital. Centralism has been replaced with decentralisation, there is a growing alienation in relation to workers and capital owners alike, while markets have become large and uncertain.

According to Karl Marx, the creations of joint stock companies represent: ${ }^{3}$

A huge increase in production scales and companies, which was impossible for individual capital; at the same time, state-owned enterprises became socially-owned;

Capital, which is based on a social way of production and which presupposes the social concentration of the means of production and workforce, takes on a form of social capital in conflict with private capital and its companies acting as social enterprises in contrast to private companies. It is the abolition of capital as private property within the limits of the capitalist mode of production;

The essentially active capitalist is transformed into a simple conductor, a manager of someone else's capital, and the owners of capital into simple owners, i.e. simple financial capitalists. Even then, when the dividends they derive include interest and entrepreneurial profit that is overall profit (because a conductor's wage is, or should be, only a wage, a kind of qualified labour, the cost of which is regulated on the labour market as well as for any other work), this

1 Horvat, Branko (1982) The Political Economy of Socialism M. E. Sharpe: Armonk, New York, translation Globus: Zagreb, p. 28.

2 Ibid, p. 30.

3 Marx, Karl Capital - III Prosveta - BIGZ: Beograd, 1979, p. 1504. 
overall profit is drawn only in the form of interest, i.e. as a mere award for property in capital. In this way, profit is represented as being simply about the usurpation of someone else's surplus labour. The joint stock company function is separated from the ownership of capital and, therefore, the work is completely separated from the means of production and surplus labour. This result of the highest development of capitalist production represents a necessary transition point for the repeated conversion of capital into manufacturer's property; not private any more, but as direct socially-owned property.

All these lead to the conclusion that capitalism, in its modern form of corporate capitalism, is opening up the problems of alienation as well as the processes of quantification and abstractionism. The world economic crisis in the $21^{\text {st }}$ century has brought and facilitated numerous debates on the topics of the developmental stage of capitalism and of the dilemma as to whether this is the evolutionary end of neo-liberalism which, at its core, has represented the thesis of the free market ('laissez faire') as a ripe stage of the evolutionary period of capitalism.

The question that is the foundation of the initial research assumptions is whether capitalism - based on the initial idea of Adam Smith (1723-1790) on the capitalist model, i.e. that the wealth of a nation is the sum of the efforts of each individual in achieving and satisfying their own interests, thus serving both social and public interests - has resulted in the alienation of the individual in the circumstances of full market liberalisation. If so, the corollary is whether this has, in turn, led to the overcoming of the existence of the theory known as neo-liberal capitalism based on market self-regulation. If we look at the causes of the crisis, the influences of stock speculators are clear and this opens up a new field of research, i.e. whether the economy, based on ideas of strict regulation, especially of the financial sector and investment by the state, has created an environment for a new economic doctrine. This second assumption again raises the issue of the economics of Karl Marx (1818-1883), who emphasised the contradictions in the development of productive forces and technology in the direction of a more humane social stage, given the simultaneous appropriation of surplus value exclusively by the private owners of capital. This leads to class differentiation and has created the unsustainability of notions for the further development of capitalism.

Furthermore, the ideas of the economist John Maynard Keynes (1883-1946), on the impact of and requirements for state intervention, have once again been highlighted. He based his doctrine on emerging from economic crisis on the basis of the principles of the funding of public projects as a means of stimulating demand and employment.

In addition to Smith's contribution, the bases of the capitalist system were established by David Ricardo (1772-1823), via the thesis that wages cover only the minimum needs of workers, and Jean-Baptist Say (1767-1832), via the law of auto restoration and the maintenance of macroeconomic equilibrium, i.e. each supply creates its own demand. ${ }^{4}$

4 Mesarić, Milan (2006) 'Dugoročna neodrživost tržišnog fundamentalizma i neoliberalnog kapitalizma’ Ekonomski pregled Zagreb 87(9-10). 
Capitalism became dominant in the seventeenth and eighteenth centuries. It passed through various stages of development in this period, but some common characteristics can be differentiated: ${ }^{5}$

The existence of politically and legally free people;

Free people (workers and employees) sell their labour power to the owner of capital in the labour market based on a contract;

The existence of the market as a mechanism that sets prices and regulates the exchange of social goods;

Each individual works with the aim of achieving profit but, due to the general competitive struggle, all participants will derive benefit from it.

Under the capitalist model in the seventeenth and eighteenth century, industry and technology were at a low level of development and human activity was based on the norms and morals of medieval culture. What is now regarded as competitive and simple market positioning was then viewed as immoral and unethical (for example, taking a customer over to another dealer due to lower prices).

So, on the basis of these considerations of capitalism, we come to the conclusion that two assumptions were dominant in society. One is an ideological philosophy focused on an analysis of the individual and his or her position in society; while the other is focused on technology and industry, with its contribution to the accelerated development of society. One observes the irrational side of society while the other observes its rational side. In the first, a negative characteristic of the capitalist model is hidden; in the other, there is a positive one. A long time ago, Francis Bacon (1561-1626) believed that the role of man in society is not to recognise the laws of nature, but to master them; while Rene Descartes (1596-1650) spoke of the need to neglect irrationality. Both philosophers, in some sense, presume the philosophical foundations of the capitalist system. The well-known critic of this system was Karl Marx.

\section{Alienation - abstractionism - commodification}

The evolutionary development of capitalism inevitably points to its influence on the development of personality. This phenomenon has both direct and indirect impacts, however: regardless of the power influences, it is evident that the process of alienation is present, i.e. in the process of the consumption of human energy via the focus on productive effort more generally. Under capitalism, a product is created at the same time as the alienation of the results of that effort, so in this way is created the indirect impact of self-alienation. The industrial revolution directly and indirectly affected human beings: the machine was the result of human labour but, at the same time, it put itself over him, endangering his work.

However, alienation in capitalism does not occur only on the side of workers but also on the side of managers and owners. The reasons for this can be found in the social forces of the capitalist mode of production which operate on the principle of inconsistency and anonymity, because each entity creates a principle of struggle in the market

5 From, Erih (1980) Healthy society Rad: Beograd, p. 99. 
within which they seek to satisfy the needs of the individual (i.e. the self). It was pointed out by From that, in any other social system, this would be called anarchy, whereas only in capitalism is it called 'the economic laws of market management'. The development of capitalism emphasises this approach and it is evident that it has become dominant in periods of economic crisis.

According to From, capitalism has endorsed the principle of the establishment of political freedoms, as opposed to central planning and a recourse to potential control; but, on the other hand, alienation caused by capitalism is made manifest through the laws created by the individual but not controlled by him. This entails a rejection of responsibility for the future and the creation of a giant state and economic systems with which it is difficult to manage. ${ }^{6}$

Understood in this way, alienation not only alienates human beings from others, but also abstracts the individual from his or her sense of self. Idolatry is developed in the form of capital and money, while everything else becomes abstractionism. An individual looks at himself and others through monetary achievements. In this way, human beings become similar to the projections of an irrational addict who is addicted to the materialised form of mind known as money.

A worker in such a system becomes as the machine created by his or her labour; hence, the conclusion of Gillespie, who states:

An individual becomes an economic atom who plays a melody of atomic management. Your place is right here; you will sit like this; your hands will move $\mathrm{x} \mathrm{cm}$ in the direction of $\mathrm{y}$ radius; and the time of motion will be $\mathrm{x}$ minutes. Work is becoming a more and more repeated and involuntary activity as planners, micro drivers and scientific organisation increasingly deprive workers of their right to think and to move freely. Life is challenged: the need to control is prevented; creativity is prevented, as is curiosity and independent thought; and the result, the inevitable result, of all these is escape, or workers' struggle; apathy, or destructiveness; and mental regression! ${ }^{7}$

A manager manages the capital invested by someone else, so he or she is estranged from the rate of return on capital. Also, within management structures, management by workers is being stressed more and more in relation to the handling of technological processes (it seems that a germ of spirit still exists). One example is the manager alienation which From sees in his own struggle with:

The faceless giants of competing companies, global markets, giant unions, giant consumers...

According to him, this is all the perfect milieu for the creation of rigid bureaucratic structural 'controllers'. This is the point where alienation turns into abstractionism, since the relationship between bureaucrats is totally alienated from individuals, while impersonality is expressed through the size of the organisation.

6 From, op. cit. p. 143-146.

7 Gillespie, J. J (1948) Free Expression in Industry Pilot Press: London. 
Just that size, according to Peter Drucker, represents the alienation of the very owner of the corporation. In Drucker's view, owner alienation from employees, managers and the corporation itself is verified through the ownership of 'a piece of paper' called the share and which stands for a deceptive amount of money. ${ }^{8}$ In this way, the owners of capital are alienated in many forms: they have become a passive owner of securities estranged from direct control; while individual wealth is often conditioned by the activity of individuals who manage their own corporations and those of others. This leads to the conclusion that property, power and responsibility are alienated from the owner and placed in the hands of the real controllers (management boards and managers).

In addition to the subjects of the creator and the owner of capital, alienation also occurs on the side of consumers, because it shape their attitudes:

If I had money I could buy an excellent picture... I would not need necessary effort to gain something... I can destroy the book or the picture I bought... So, the method of obtaining is alienated from the method of usage.

However, these processes of alienation and abstraction will construct a system of social commodification that will lead to the complete concretisation of relations between people. Of course, an instrument of such concretisation is expressed in a form of capitalism, i.e. super-capitalism, so named by From, while Marx expressed it in The Poverty of Philosophy in the following form:

Ultimately, the time has come when all things that people considered thus far as inalienable have become the subject of exchange or sale and which could be alienated... these were things that could be exchanged, given, but never bought: virtue, belief, conscience and knowledge and so on - in a word, everything has become the subject of trade. It is a time of general corruption and sale, i.e. the time at which each subject, physical or moral, is brought to the market as the object of exchange in order to be evaluated there according to its true value. ${ }^{9}$

Thus did market relations become the standard of being and existence. Furthermore, in the era of super-capitalism, as long as profit is alienated from workers, enthusiasm will be in a depressed form. Thus, Lincoln believes that only the development of the individual will precipitate the regaining of the enthusiasm and the reduction of the discontent of workers, alongside the creation of a market of satisfied customers, which will create a healthy society. It is also pointed out by From that the main argument in favour of capitalism was an idea of profit and its materialisation manifested by work; thus, a parallel can be drawn with socialism because, to that system, materialism is mostly imputed, but the objectivity of socialism is precisely the opposite, since it criticises materialism and its negative impact on the sense of self.

8 Drucker, Peter (1946) Concept of the Corporation John Day: New York, p. 8-9.

9 Marx, Karl Poverty of Philosophy Prosveta: Beograd, 1980, p. 57. 


\title{
What is common to the crises?
}

Marx divides capitalists into monetary and industrial capitalists, the former making interest and the latter entrepreneurial profit. He also points out that most capitalists work with borrowed capital, which means that both types use capital for different purposes and, therefore, have a different role in the process of reproduction. For the productive capitalist using borrowed capital, profit has two prefixes: interest rate profit; and gained profit. Marx comes to the conclusion that:

\begin{abstract}
Interest is the fruit of capital by itself, the ownership of capital, regardless of the production process; and entrepreneurial profit is the fruit of capital that is processing, that is operating in the production process and hence the active role which the applicator of capital plays in the process of reproduction. ${ }^{10}$
\end{abstract}

From Marx's previous statement derives the understanding, and dilemma, whether the capitalist is the owner of capital. Withdrawing the parallel between the previous statement and the state of the development of capital markets, i.e. the increasing scope of the usage of borrowed capital, it is clear what has caused the frequent crises in recent decades. So, a level of alienation also comes to capital, in terms of its roles and mode of usage. A high degree of self-financing ensures independence of financial markets and reduces the possibility of economic crises.

In their evolutionary development of capitalism, the subjects of economic activity grew more complex so that a system of alienation was becoming more emphatic for all (workers, managers and owners). Each phase of capitalism ended in a particular crisis. In the 19th century, commercial capitalism ended in the 1847 crisis and, according to Marx, one of the main causes of this crisis was a glut on the market and extensive speculation; and then in the 1857 crisis as well as that of 1866/67. Industrial capitalism also ended in crisis - the Great Depression of 1929-33 (via an over-stated value of securities and a stock market crash: 'Black Thursday'); then there came the oil crisis of the 1970s. Each phase of the ending of capitalism led Engels to the view, confirmed by today's events, that crises are an acute form of a periodic process with a prior cycle of ten years, developed into a chronic stage of successive short, weak improvements with a relatively long depression, and is perhaps reduced to a particularly extensive continuance of the cycle. Evidently, it remains to see whether the 2008 crisis marks the end of corporate capitalism.

The assumption of a market economy is that consumers make a choice of goods which satisfy their needs, while manufacturers produce those products that maximise profit and which have the lowest costs. This implies that the most profitable are those products that are the most valuable for consumers and that market participants thus create economic prosperity. ${ }^{11}$ This exactly represents the thesis of the laissez faire market. This economic model assumes security, certainty and the availability of information. However, if it is known that the conditions in which the economic market functions are symbolised by uncertainty, insecurity and a lack of information, then this

10 Marx, Karl Capital III Prosveta: Beograd, 1979, pp. 1447-1448.

11 Horvat, Branko op. cit. p. 270. 
opens up the problems of market instability due to price flexibility and the question of the correctness of consumers' and producers' choices, based on available information. According to Keynes, such an individualistic conception of profit may lead to social loss. Does this understanding demand a planning of the market, as opposed to the laissez faire market, so that individualism could be replaced by the well-being of the community?

In this context, planning is based on the proper functioning of forecasting instruments and the co-ordination of economic decisions and initiatives. Does the diversity of these instruments determine the character of the economic system, depending on the dominant form? There are five types of regulatory mechanism: ${ }^{12}$

1. the laissez faire free market. This instrument was the conjunction of the transition from the feudal to the capitalist system, i.e. the transition from individualistic, feudal economies of small traders into a common national economy. The state has had the role of guarantor of property. On this basis, Smith developed the theory of the 'invisible hand'

2. a non-conformity between solvent and social demand indicated the unsustainability of the theory of the 'invisible hand'. Therefore, the instrument of the 'visible hand' appeared as an instrument of co-ordination, in which private initiative is replaced by central planning of the market - i.e. by administrative planning

3. a level of animosity between central planning and private property led to a need to create a new mechanism: the state as an organisation of economic policy

4. the informatics revolution revived the idea of the 'market hand', but now in a symbiosis of the 'visible and invisible' types. On the one hand, access to information and the speed of access opens up the possibility of a higher level of free market but, on the other, the ability to process information and archive it creates a potential for state centralism

5. non-market instruments of co-ordination (non-administrative controls), types of agreements, arbitration and consultations have improved the operation of 'the visible hand'.

All five types of regulatory mechanism define the different developmental stages of economics: free market - liberal capitalism; administrative planning - statism; economic policy - Keynesian model; production and the use of information, and the coordination of non-market instruments - corporate capitalism and the welfare state. The five regulatory mechanisms also mark socialism at its various stages. The next stage of economic development is certain.

\section{Humanisation or the nihilism of individual rights?}

In his work The Revolution of Hope, From raises the question of whether the wealthy (From refers to Americans, but this question may well apply to all individuals) should abolish the permanent increase in consumption, which he calls an endless and unintelligent process, while the state, at the same time, continues its expansive growth. He also raises the dilemma of whether there is a limit to production and consumption or whether their correlation leads to an indefinite increase. He believes that the growth of 
production is the means for achieving a goal, not the goal itself. The means that allow productive energy to turn into truly human development, not through materialisation but through intellectual growth and existence, lead From to endorse the views of John Stuart Mill who, among other things, said:

If the country had to lose this big part of its bounty, thanks to things that are incompatible with the unlimited increase of land and population, only in achieving the goal of the support of a numerous but not better and happier population, I do sincerely hope for the best for future generations and wish them to be satisfied by a state of rest long before being compelled by necessity. ${ }^{13}$

Arising out of this claim, From finds that a delay in the increase of capital, which we are witnessing today, does not necessarily encompass a delay in the progress of human culture. On the contrary, he sees in this the opportunity for the renaissance of alienated people and for the assumption of the planning of those values that have become to be considered old-fashioned and outdated. And this immediately raises the question of what the economic system is supposed to look like so as to match the principles of technology which have been established and, at the same time, to limit dehumanised spending. From finds the solution in the planning process, but not privately through arrogance and the greatest symbol of alienation - giant corporations but through the principle of systematic planning at the level of society as a whole: a system established by competitive advantage based on the broad range of integration and related and supporting activities, and providing the synchronisation of the plan through several economic activities at societal level. In this way, inhuman, mattermystified society would come to reflect the mental and intellectual development of human society. In his time, From already observed that the solution lies in those means that many academics have mentioned and promoted through various forms of strategies, such as: the revitalisation of rural and suburban areas; the expansion of the networks of public education and healthcare; the development of transport infrastructure; cultural revival; etc. A new attitude can then become: to exist, but not to possess and to spend.

\section{The curse of greatness and the nihilism of capitalism}

If we now turn to the characteristics of the existing level of the development of society (q.v. capitalist development), it is easy to observe the phenomenon of credit financing. Credit financing accelerates the turnover and hence the metamorphosis of goods, too i.e. the process of reproduction in general. However, Marx says that this acceleration, on the other hand, separates the act of buying and selling as time passes and, therefore, is a subject of frequent speculation. Within these processes he sees the alienation of capital from capitalism. In this, he sees: ${ }^{14}$

The huge increase of production scopes and companies which were impossible for individual capital. At the same time, such previously state companies become social ones.

13 Taken form: From, Erih (1980) The Revolution of Hope Grafos: Beograd, p. 136.

14 Marx, Karl op. cit. pp. 1504-1506. 
Capital, which rests on a social way of production and presupposes a social concentration of the means of production and workforces, takes the form of direct social capital (associated individuals) as opposed to private capital. It is the abolition of capital as private property within the limits of the capitalist mode of production.

The transformation of the actually active capitalist into the simple conductor-manager of somebody else's capital - on the one side - and capital owners into simple owners, simple financial capitalists - on the other.

In this way, the entire production of some branches is concentrated into one large joint-stock company with a single administration.

According to Marx, this leads to the abolition of the capitalist mode of production from within itself. Hence, it embodies its own contradictions and points to the need for a transition to a new form of production.

In certain areas, it establishes a monopoly and, therefore, leads to the interference of the state. It reproduces a new financial aristocracy, a new type of parasite in the form of designers, founders and nominal directors, the entire system of machination and deception regarding the establishment and issuance of shares and trading in shares. It is private production without the control of private production. ${ }^{15}$

Thus, Marx sees the abolition of capitalism as having a direct interface with credit and the principle of using someone else's capital, as well as other people's property and someone else's work. It abolishes private property and the possession of capital which provides the superstructure for credit. This hence forms a parallel with economic crises, which are mostly the result of speculative stock manipulation, i.e. the management of someone else's capital.

Therefore, the system of credit, which lay behind the assumption of a transition from individual to corporate production, has become the main basis for the expansion of capitalist joint-stock companies which have a national scale. This system also accelerates the material development of productive forces and leads to excessive production and consumption, and to excessive speculation, speeding up the processes of contradiction, causing economic crises worldwide and creating the assumptions and elements of a capitalist nihilism. Exchange, in that context, represents the statist milieu of the capitalist system, with elements of a life-giving element. In the early stages of the development of capitalism, exchange was used for the accelerated development of the capitalist order and, then, the acceleration of the basic principles of capitalism led to the multiplication of negative elements and to a process of self-destruction. In the nineteenth century, the securities market was small, so exchange had a secondary role. However, by the end of the nineteenth century, it drove an acceleration of monetary capital because accumulated capital was overcoming the needs of consumption and production growth. Industry became transformed into joint stock companies, from which point the process of nihilism began. The owners of capital become 'the owners of the theatre, the orchestra which is conducted by others', a banking system is de- 
veloped based on mortgage and the stock market becomes a place where 'supreme property' is sold, not the actual value.

Shareholders with a limited ownership of capital have limited liability, and stock companies dispose of 'permanent succession' regardless of the owners of capital. ${ }^{16}$ Alienation is becoming another name for the company.

Samuelson points to the view that shares, from the standpoint of investors, represent gradually increasing risks and lesser and lesser security, although compensation is found in high rates of profit. However, corporations' gigantism carries the curse of size, according to Samuelson. He believes that such levels of gigantism create a monopoly and, thereafter, the need for a response from the state. In this sense, he raises the dilemma that selection will not be between corporations and their competitors but in the modes of the choices made in the direction of improvement of the social and economic results of the aggregates of large corporations. ${ }^{17}$ In his view, these corporations should be directed to work for the public good, implying the entry of the state to the scene and to Keynesian interventionism. In other words, today's events point to the problem of finding lasting solutions in the form of a new ethical doctrine which has for its goal a review of the objective scopes and historical limitations of the capitalist mode of production. ${ }^{18}$

If we consider Max Weber's claim that the capitalism of the time was based on the creative power of human labour, can alienated labour be completely considered as a motor force for changes within the Protestant spirit of capitalism towards a new ideology? In addition, do economic crises, with their rising historical echoes, represent a warning to the human spirit? And, ultimately, is the human spirit, in its genuine beginnings, incarnated in human work through a positive or a negative attitude? ('God made the earth' - a positive view of work; 'Cursed is the earth because of you; you will eat of it with passion all your life' - a negative attitude.)

So, work as a moving force for production relations may be observed not only in terms of productivity but also in terms of ethical and moral principles. This has a constant moral value, although some systems of social organisation, such as the capitalist mode of production, are, through the processes of the alienation of the creators of work and, furthermore, of the users of its effects, opening a new chapter in the overall system of social relations. On the one hand, new forms of ethical and moral norms are opening up, but these represent also a postulate of the new values manifested through various types of reform in the systems of society. Within this scale of understanding of its norms and values, capitalism really does 'eat its own babies'.

\section{References}

Dess, Lumpkin and Eisner (2007) Strategijski menadžment Data Status: Beograd.

Dragičević, T and V. Pavlović (2008) Značaj i uloga izveštaja o korporativnom upravljanju SYMORG, Zbornik radova: Beograd.

16 Samuelson (1969) Economics Savremena administracija: Beograd, p. 7.

17 Ibid.p. 107.

18 Marinković, Darko Protestantska etika i duh kapitalizma-drugi put. 
Dragičević, T and M. Živković (2009) Corporate Management During the Crisis 7th International Scientific Conference: 'Dealing with the Global Economic Crisis in Companies and Economies' Belgrade, 27 November.

Drucker, Peter (1946) Concept of the Corporation John Day: New York.

From, Erih (1980) Revolucija nade Grafos: Beograd.

From, Erih (1980) Zdravo društvo Rad: Beograd.

From, Erih (1983) Bekstvo od slobode Nolit: Beograd.

Gillespie, J. J. (1948) Free Expression in Industry Pilot Press: London.

Horvat, Branko (1982) The Political Economy of Socialism M. E. Sharpe: Armonk, New York, prevod Globus: Zagreb.

Lavelle, Jespersen (2002) ‘Executive pay’ Business Week 15 April.

Marinković, Darko Protestantska etika i duh kapitalizma - drugi put.

Marx, Karl Kapital tom I-III, Prosveta: Beograd, 1979.

Mesarić, Milan (2006) 'Dugoročna neodrživost tržišnog fundamentalizma i neoliberalnog kapitalizma’ Ekonomski pregled Zagreb 87(9-10).

OECD Principles of Corporate Governance - 2004 Edition, OECD.

Samuelson (1969) Ekonomija Savremena administracija: Beograd.

Smith, A Bogatstva naroda Global Books: Novi Sad, 1998. 